Article

\title{
Potent activity of high concentration ozone therapy against an- tibiotic-resistant bacteria
}

\author{
Karyne Rangel 1,2*, Fellipe O. Cabral 3, Guilherme C. Lechuga 1,2, João P. R.S. Carvalho ${ }^{1,2}$, Maria H.S. Villas-Bôas ${ }^{3}$, \\ Victor Midlej ${ }^{4}$ and Salvatore G. De-Simone ${ }^{1,2,5, *}$
}

1 FIOCRUZ, Center for Technological Development in Health (CDTS)/ National Institute of Science and Technology for Innovation in Neglected Population Diseases (INCT-IDPN), Rio de Janeiro, RJ, 21040-900, Brazil. karyne.rangel@cdts.fiocruz.br (K.R.); guilherme.lechuga@cdts.fiocruz.br (G.C.L.); joaopedrorsc@gmail.com (J.P.R.S.); salvatore.simone@fiocruz.br) S.G.D-S.;

2 Laboratory of Epidemiology and Molecular Systematics (LESM), Oswaldo Cruz Institute, FIOCRUZ, Rio de Janeiro 21040-900, RJ, Brazil.

3 Microbiology Department, National Institute for Quality Control in Health (INCQS), FIOCRUZ, Rio de Janeiro, RJ, 21040-900, Brazil. fellipe.cabral@incqs.fiocruz.br (F.O.C.); maria.villas@incqs.fiocruz.br (M.H.VB.).

4 Laboratory of Cellular and Ultrastructure, Oswaldo Cruz Institute, FIOCRUZ, Rio de Janeiro, RJ. Brazil. victor.midlej@ioc.fiocruz.br (V.M.)

${ }_{5}^{5}$ Department of Molecular and Cellular Biology, Biology Institute, Federal Fluminense University, Niterói, RJ, 22040-036, Brazil.

* Correspondence: karynercarvalho@cdts.fiocruz (K.R, +552138658240); salvatore.simone@fiocruz.br (S.G.D-S $+552138658183)$

\begin{abstract}
Background: Health Care-Associated Infections (HAIs)are a significant public health problem worldwide favoring multidrug-resistant (MDR) microorganisms. The SARS-CoV-2 infection had a negative association with the increase in antimicrobial resistance, and the ESKAPE group had the most significant impact on HAIs. The study aimed to evaluate the bactericidal effect of high concentration $\mathrm{O}_{3}$ gas on some reference and ESKAPE bacteria. (2) Material and Methods: Four standard strains and four clinical or environmental MDR strains were exposed to high ozone doses at different concentrations and times. Bacterial inactivation (growth and cultivability) was investigated using colony counts and resazurin as a metabolic indicator. Scanning electron microscopy (SEM) was performed. (3) Results: The culture exposure to a high level of $\mathrm{O}_{3}$ inhibited the growth of all bacterial strains tested with a statistically significant reduction in colony count compared to the control group. The cell viability of S. aureus (MRSA) $(99,6 \%)$ and P. aeruginosa (XDR) $(29,2 \%)$ was reduced considerably, and SEM showed damage on bacteria after $\mathrm{O}_{3}$ treatment (4) Conclusion: High doses of ozone were able to interfere in the growth of all strains studied, evidencing that ozone-based decontamination approaches may represent the future of hospital cleaning methods.
\end{abstract}

Keywords: ozone; detrimental effect; pathogenic bacteria; antimicrobial resistance; SEM; ESKAPE pathogens

\section{Introduction}

Health Care-Associated Infections (HAI) are a significant public health problem worldwide, especially in developing countries where the frequency can be at least three times higher than in developed countries [1]. It is estimated that approximately four million people annually acquire HAIs in the European Union (EU) and that some 37,000 persons die due to resistant infections acquired in hospital environments. Most of these 
deaths (67.6\%) are caused by multidrug-resistant (MDR) bacteria to antimicrobials [2]. The 2016 European Annual Report recorded the Incidence Density (DI) for VentilatorAssociated Pneumonia (VAP) of 3.9/1000 days, central catheter-associated bloodstream infections (CCAB) of 1.7/1000 days, and infections urinary tract related to a catheter (ITURC) of 2.1/1000 days [2], while in Brazil, the DI of device-related HAI in the year 2016 indicated PAV of 13.6/1000 days, ICSACC of 4.6 /1000 days and ITURC of 5.1/1000 days [3]. The increasing burden of HAIs stemming from poor infection monitoring and control practices are among the drivers of antimicrobial resistance. Evidence indicates a strong relationship between antimicrobial resistance and HAI [4], with MDR pathogens being a common cause [5,6]. Although they are frequent adverse events, with high morbidity and mortality rates and high costs, HAIs are recognized as preventable in up to $70 \%$ of cases [7].

Antimicrobial resistance (AMR) is a consequence of bacteria's natural evolution and adaptation processes. However, selection pressure has accelerated it, originating from the inadequate or excessive use of antimicrobials, favoring MDR microorganisms' appearance and rapid spread [8-10]. The problem is highlighted in the ICU, where patients have higher risk factors for nosocomial infections. In addition, the cost of antimicrobial resistance in these infections is very high, as diseases caused by these pathogens have worse clinical outcomes, prolonged hospital stays, and increased mortality rates [11]. Every year, more than 700,000 deaths are associated with AMR [12,13], and by 2050, the number of lives lost annually could reach 10 million [14]. The COVID-19 pandemic was declared by the World Health Organization (WHO) on March 12, 2020 [15-17], and at that time, the disease was spreading rapidly since the first detection of the SARS-CoV-2 coronavirus in Wuhan, China, in December 2019 [18]. The SARS-CoV-2 infection had a negative association with the increase in antimicrobial resistance for reasons related mainly to the rise in the practical use of antimicrobials, overcrowding of health systems, lack of management measures, and decrease in the pace of activity of laboratories in surveillance cultures and diagnostic tests to detect antimicrobial-resistant organisms.

On the other hand, the lower impact on the development of antimicrobial resistance may be associated with increased infection control measures adopted to prevent the contamination of healthcare professionals with SARS-CoV-2, including hand hygiene and the use of protective equipment individual and devices to decontaminate the air and surfaces [19]. According to some studies, up to 5\% of patients infected with SARS-CoV-2 had to be admitted to the ICU [20,21]. In addition, it has been documented that up to 50\% of these patients may have had secondary bacterial infections or superinfections, mainly bacteremia and urinary tract infections [22,23]. These infections are more prevalent in terminally ill patients and are primarily due to the spread of MDR pathogens.

Among the MDR pathogens, those from the ESKAPE group had the most significant impact on HAIs. Also called "super bacteria," they group six pathogens that can escape the biocidal activity of antimicrobials: Enterococcus faecium, Staphylococcus aureus, Klebsiella pneumoniae, Acinetobacter baumannii, Pseudomonas aeruginosa, and Enterobacter spp. [24-32]. The inefficiency of antimicrobials against these pathogens is due to several resistance 
mechanisms, such as drug inactivation, modification of drug binding sites/targets, changes in cell permeability, and mutation [33]. As a result, these pathogens can survive in the hospital environment for a more extended period and can be transported from one individual to another, thus spreading in the community and hospital [34].

A priority list of antimicrobial-resistant bacteria was described in 2017 by the WHO to support renewed efforts in researching and developing new antimicrobials, diagnostics, vaccines, and other tools [35]. Most ESKAPE pathogens appear on this list of most problematic microbial species, which appeals to focus research efforts on this topic [35]. The European Centers for Disease Control (ECDC) and the US Centers for Disease Control (CDC) provided the following standardized definitions for MDR, extensively drugresistant (XDR) and pan-drug resistant (PDR) bacteria. MDR bacteria are defined as those with acquired resistance to at least one agent in three or more categories of antimicrobials. XDRs are those that are not susceptible to at least one agent in all classes of antimicrobials except two or fewer types (i.e., remain sensitive to only one or two categories). Bacteria resistance to all agents in all antimicrobial types is called PDR [36]. The environment plays a central role in the transmission of hospital-acquired pathogens and the pathogenesis of HAIs.

Many bacteria, especially MDR, can survive in the hospital environment for several months, particularly in areas close to patients. Among the factors that favor the contamination of the health services environment, we can mention the hands of health professionals in contact with the surfaces, maintenance of damp, wet, and dusty surfaces, precarious conditions of coatings, and maintenance of organic matter [37-38]. The presence of dirt, mainly organic matter of human origin, can serve as a substrate for the proliferation of microorganisms or favor the presence of vectors, which can passively carry these agents. Hence the importance of rapid cleaning and disinfection of any area with organic matter, regardless of the hospital area $[39,40]$. The effective disinfection of surfaces and the environment is considered one of the primary measures to control the spread of HAI. Many studies have concluded that current cleaning methods are microbiologically ineffective. This failure concerns daily cleaning and final cleaning after the patient is discharged. Improvements in environmental cleanliness are associated with a decrease in the rate of hospital-acquired pathogens and HAIs [41]. In the last year, a new global emergency introduced the requirement for further disinfection and sanitization procedures to optimize the quality of care and work safety in professional environments [42-51].

Considering the increasing prevalence of MDR microorganisms in hospitals, which has become a severe threat to public health, the study of alternative methods and/or agents for disinfection and sanitization should receive special attention, and ozone is an option that can use with different objectives $[52,53]$. Ozone is a blue-colored gas with a characteristic odor, presented in the triatomic form of oxygen $\left(\mathrm{O}_{3}\right)$, partially soluble in water and highly unstable, decomposing quickly into oxygen. Therefore, it cannot be produced in large quantities without forming a continuous [54]. With an oxidative potential superior to most commercial disinfectants, reacting faster than $\mathrm{O}_{2}$, it has been 
studied for decades in medicine and biological sciences, becoming a versatile therapeutic agent, which helps treat several diseases [55]. It is used in several food industry segments, the disinfection of environments, and the manufacture of products [56]. Also used in wastewater treatment plants [57], in supporting treatment in veterinary therapy [58], and in various areas of engineering [59]. In the health sector, it plays an essential role in the control of microorganisms, such as in the treatment of hospital waste [60], disinfection of hemodialysis machines [61], disinfection of surgical environments [62], treatment of periodontitis [63], among others. Currently, with the COVID-19 pandemic, ozone has been investigated as a possible preventive measure for the spread of infection [64], in hospital hygiene for disinfecting rooms [65,66], in viability on different surfaces [67], and as a therapeutic option in the treatment of patients [68-70]. Ozone acts first on the cell membrane as a disinfectant, reacting with glycoproteins, glycolipids, and nucleic acids. Microorganisms are inactivated by cell disruption due to the action of molecular ozone or free radicals during the decomposition of the gas [71-74]. Studies show that ozone influences the global polarity of the bacterial surface [75], involving mechanisms of lipid peroxidation [76,77] and degradation of transmembrane proteins that control the flow of ions. Thus, cells rupture leakage of ions between the media, resulting in the microorganism's death [78].

Despite having been used in the hospital environment for some time, little is known about the potential of this agent, especially in the Brazilian context, where studies on the subject are scarce. Therefore, from this perspective and due to the aspects reported, there was an interest in evaluating the bactericidal action of high concentration ozone gas on some reference bacteria used in the process of assessing the bactericidal activity of disinfectants and some bacteria from the ESKAPE group that have a high resistance profile antimicrobial.

\section{Materials and Methods}

\subsection{Bacterial strains}

Standard strains (Staphylococcus aureus (ATCC 6538), Salmonella enterica subsp enterica serovar choleraesuis (ATCC 10708), Escherichia coli (ATCC 25922), and Pseudomonas aeruginosa (ATCC 15442) were obtained from the American Type Culture Collection (ATCC) (Plast Labor Ind. Com. EH Lab. Ltda, Rio de Janeiro, RJ, Brazil). Representative MDR strains of the ESKAPE group were also used, with four clinical strains isolated from HAI, which were: methicillin-resistant S. aureus (MRSA), carbapenemase-producing K. pneumoniae (KPC+), A. baumannii PDR carrying the blaoxA-23 gene and representing one of the genotypes disseminated in Brazil (ST15 / CC15) and an environmental strain of P. aeruginosa (XDR) from hospital effluent was also used. These strains were kindly provided by Dr. Maria H. S. Villas-Bôas (National Institute for Quality Control in Health of the Oswaldo Cruz Foundation-INCQS/FIOCRUZ) and by Dra. Catia Chaia de Miranda (Interdisciplinar Medical Research Laboratory, LIPMED, FIOCRUZ). These bacterial strains were initially cultivated according to the instructions of the ATCC, aliquoted, and stored in cryotubes containing Tryptic Soy Broth (TSB, Difco) with $20 \%$ glycerol (v/v) and kept at $-20^{\circ} \mathrm{C}$ for later use.

\subsection{Ozone generating and monitoring}


The ozone generating equipment (SANITECH O3-80-Sanitization, Astech Serv. and Fabrication Ltda., Petrópolis, RJ, Brazil) with ozone concentration adjustable from 10 to 80 ppm and capacity to treat the room air up to $1000 \mathrm{~m}^{3}$ (not habitable) was used. The monitoring and measurement of the environmental concentration of $\mathrm{O}_{3}$ emitted were realized using two portable electrochemical ozone detection modules (model ZE14-O3) (Zhengzhou Winsen Electronics Technology Co., Ltd, Honã, China). In addition, this equipment was coupled to a module containing a digital temperature and relative humidity sensor (model AM2302) (Guangzhou ASAIR Electronic Co., Ltd., Guangzhou, China). The ZE14-O3/AM2302 modules constantly monitored these three parameters during the entire experiment, with detection in 2-3 sec and simultaneous recording in a computer. The measurement was made with the ZE14-O3/AM2302 (Sensors 1 and 2) inserted directly inside each container, always on the first shelf.

\subsection{Inoculation of the test surface}

The strains were removed from the freezer stock culture for bacterial reactivation, sown in TSB, and incubated at $37^{\circ} \mathrm{C}$ for $24 \mathrm{~h}$. After the microorganisms were suspended in sterile $0.85 \%$ saline and the concentration of $10^{8}$ colony-forming units (CFU) $\mathrm{ml}^{-1}$ was determined with a densitometer (Densichek Plus, BioMérieux, USA). The successive dilutions $\left(10^{5}\right.$ and $\left.10^{4} \mathrm{CFU} \mathrm{ml} \mathrm{m}^{-1}\right)$ were made in the Brain Heart Infusion broth (BHI). One hundred microliter aliquots of each bacterial suspension (S. aureus, S. enterica, E. coli, $P$. aeruginosa, S. aureus (MRSA), K. pneumoniae (KPC+), A. baumannii (PDR), and $P$. aeruginosa $(\mathrm{XDR})$ in different concentrations $\left(10^{5}\right.$ and $\left.10^{4} \mathrm{CFU} \mathrm{ml}{ }^{-1}\right)$ were plated in triplicate by spread plate on Triptona Soy Agar (TSA; Difco) and incubated at $37^{\circ} \mathrm{C}$ for 24 h.

\subsection{Ozone treatment}

The ozone generated was infused into two hermetically sealed containers, with a volume of approximately $1 \mathrm{~m}^{3}$ each (Figure S1). The plates inoculated with the different microorganisms were placed open on the shelves inside each container. After closing the lid of each container, we started the exposure to ozone using only one SANITECH O3-80Sanitization equipment, producing ozone at a concentration of 80 ppm (maximum) (Figure S1). ATCC strains were exposed to ozone for 1, 10, 20, 30, and 40 minutes (min). According to the results obtained with the reference strains, we verified that the initial concentration of the inoculum $\left(10^{4}\right.$ or $\left.10^{5} \mathrm{CFU} / \mathrm{mL}\right)$ had no significant interference in the colony count results, but rather the time of exposure to ozone that presented the best impact to the $40 \mathrm{~min}$. As a result, the other strains (ESKAPE) were exposed to ozone at a concentration of $10^{5} \mathrm{CFU} / \mathrm{mL} / 40 \mathrm{~min}$. The ozone-generating equipment takes time to reach its maximum concentration (ppm). For this reason, for each exposure time determined, added 2 min the readings were considered after this initial time. After the exposure time, were immediately opened the container, the plates were closed and incubated at $37^{\circ} \mathrm{C}$ for $24 \mathrm{~h}$. As a positive control for the assay, we used plates with TSA containing the same bacterial suspensions but without exposure to ozone. These plates remained at room temperature and were incubated at $37^{\circ} \mathrm{C}$ for $24 \mathrm{~h}$ together with the plates exposed to ozone. 
A plate containing only TSA was used as a negative control. The test was performed in triplicate. Colony counting was performed only on plates with many colonies from 0 to 300.

\subsection{Cell Viability}

The cell viability was measured on selected bacterial suspension of $10^{5} \mathrm{CFU} \mathrm{ml} \mathrm{m}^{-1}$ after 40 min exposure to $\mathrm{O}_{3}$ based on previous results (cell count- $\mathrm{CFU} \mathrm{ml} \mathrm{m}^{-1}$ ). The entire previous experiment was performed again (at the defined concentration and time), and after $24 \mathrm{~h}$ of incubation, three distinct colonies from each plate were inoculated separately in a test tube containing TSB broth (Difco). As a positive control of the assay, we performed the same procedure with the plates that were not exposed to $\mathrm{O}_{3}$, where three distinct colonies of each dish were inoculated separately in a test tube containing TSB broth (Difco). Afterward, $100 \mu \mathrm{L}$ of the bacterial suspension of each colony was transferred, in triplicate, to the wells of the 96-well microplate, which was incubated at $37^{\circ} \mathrm{C}$ for $24 \mathrm{~h}$. Each strain was tested in duplicate and detected bacterial growth by adding $0.02 \%$ resazurin (7-hydroxyphenoxazin-3-one 10-oxide; Sigma-Merck, St Louis, MO, U.S.A.) 1 h incubation [79]. Resazurin is a non-toxic, non-fluorescent blue reagent that, after enzymatic reduction, becomes highly fluorescent. This conversion occurs only in viable cells, and as such, the amount of resorufin produced is proportional to the number of viable cells in the sample [80-82]. As a negative control, we used TSB broth, and the measured at $590 \mathrm{~nm}$ was made on an ELISA plate reader (Flex Station 3; Molecular Devices, San José, CA, U.S.A.).

The collected data were analyzed using the program $R$ (version 3.6.0) and R Studio, where the paired t-test was applied to compare the statistical significance between the two samples (with and without treatment with $\mathrm{O}_{3}$ ) with $\leq 0.01$. Each experiment was repeated three times for each microorganism treated with $\mathrm{O}_{3}$.

\subsection{Scanning electron microscopy (SEM)}

SEM visualizes morphological changes in the bacteria species. For analysis, control cells under $\mathrm{O}_{3}$ treatment were fixed for $1 \mathrm{~h}$ with $2.5 \%$ glutaraldehyde in $0.1 \mathrm{M}$ cacodylate buffer. After fixation, the cells were washed three times in PBS for $5 \mathrm{~min}$, post-fixed for 15 min in $1 \%$ osmium tetroxide (OsO4), and rewashed three times in PBS for $5 \mathrm{~min}$. Next, the samples were dehydrated in an ascending series of ethanol $(7.5,15,30,50,70,90$, and 100\% ethanol) for 15 min each step, critical point dried with $\mathrm{CO}_{2}$, sputter-coated with a 15-nm thick layer of gold and examined in a Jeol JSM 6390 (Tokyo, Japan) scanning electron microscope.

\section{Results}

\subsection{Monitoring of ozone concentration}

Monitoring the $\mathrm{O}_{3}$ concentration inside each container showed that the average ozone emission from the equipment ( 1 to $40 \mathrm{~min}$ ) ranged from $21.1 \mathrm{ppm}$ to $71.7 \mathrm{ppm}$, with the average of all measurements being 43.9 ppm (Figure 2). The mean ozone concentration in the 40 min time chosen for testing with the MDR strains was 30.8 ppm (Figure 1). The ambient temperature ranged from $22.5^{\circ} \mathrm{C}$ to $24.3^{\circ} \mathrm{C}$, with an average of $23.4^{\circ} \mathrm{C}$. Regarding the relative humidity of the air, it went from $71.4 \% \mathrm{RH}$ to $75.5 \% \mathrm{RH}$, with an average of $74.2 \%$ RH (Table 1, Figure 1). 
Table 1. Monitoring ozone concentration, temperature, and humidity of different bacterial strains after exposure to ozone.

\begin{tabular}{cccc}
\hline $\begin{array}{c}\text { Ozone Exposure } \\
\text { Time (minutes) }\end{array}$ & \multicolumn{3}{c}{ Evaluated parameters } \\
\cline { 2 - 4 } & $\begin{array}{c}\text { Temperature } \\
\left({ }^{\circ} \mathrm{C}\right)\end{array}$ & $\begin{array}{c}\text { Relative Humidity of Air } \\
(\% \mathrm{RH})\end{array}$ & $\begin{array}{c}\text { Ozone Concentration } \\
(\mathbf{p p m})\end{array}$ \\
\hline $\mathbf{1}$ & 22,5 & 77,2 & 71,7 \\
\hline $\mathbf{1 0}$ & 22,8 & 74,6 & 48,8 \\
\hline $\mathbf{2 0}$ & 23,7 & 75,5 & 47,2 \\
\hline $\mathbf{3 0}$ & 23,9 & 71,4 & 21,1 \\
\hline $\mathbf{4 0}$ & 24,3 & 72,4 & 30,8 \\
\hline Mean & 23,4 & 74,2 & 43,9 \\
\hline
\end{tabular}

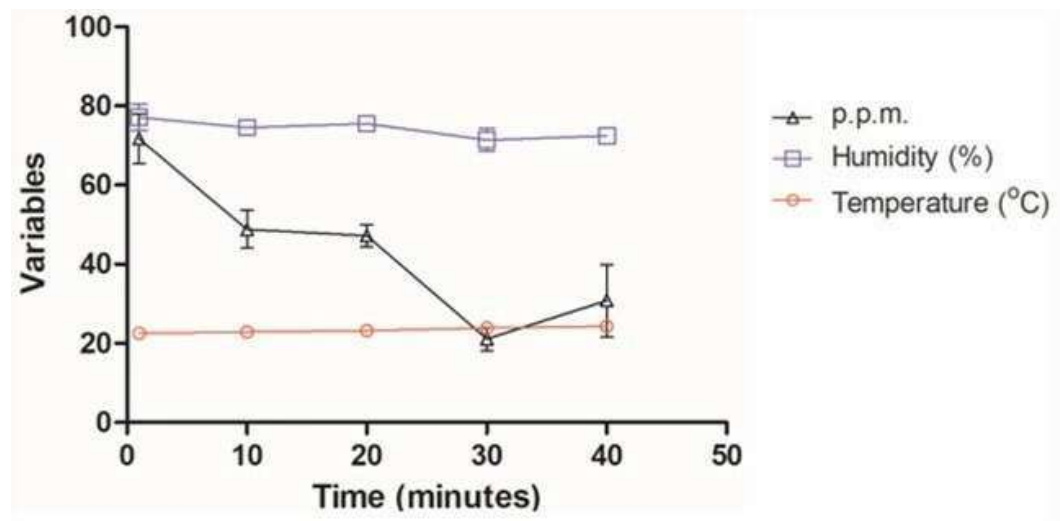

Figure 1. Average temperature, relative humidity, and ozone concentration at times of 1, 10, 20, 30, and 40 min with ATCC (S. aureus (ATCC 6538), P. aeruginosa (ATCC 15442), S. enterica (ATCC) strains 10708), and E. coli (ATCC 25922) and multidrug-resistant S. aureus (MRSA), P. aeruginosa (XDR), A. baumannii (PDR) and K. pneumoniae (KPC+).

\subsection{Ozone treatment}

The culture exposure at different times ( 1 to $40 \mathrm{~min}$ ) with a high level of gaseous $\mathrm{O}_{3}$ was able to inhibit the in vitro growth of all bacterial strains tested (Figure 1 and 2) with a statistically significant reduction in colony count compared to the control group (not treated with ozone) (Table 2). Among the ATCC strains $\left(10^{5} \mathrm{CFU} / \mathrm{mL}\right), P$. aeruginosa (ATCC 15442) was the only one that did not suffer a significant reduction in the CFU count with only $1 \mathrm{~min}$ of exposure to ozone with a reduction of only $17.5 \% \mathrm{CFU}$. The other strains significantly reduced the number of colonies, with the most significant reduction being for S. enterica (ATCC 10708) (90.4\%), followed by E. coli (ATCC 25922) and S. aureus (ATCC 6538) (both 98\%). After $10 \mathrm{~min}$ of exposure to ozone, all ATCC strains showed a 
significant reduction in the number of CFU counts, being $S$. aureus (ATCC 6538), 99.4\%, $P$. aeruginosa (ATCC 15442), 93.2\%, and S. enterica (ATCC 10708), 95.1\%. E. coli (ATCC 25922) maintained the same percentage reduction of $98 \%$. From $20 \mathrm{~min}$ to $40 \mathrm{~min}$ of exposure to ozone, all ATCC strains showed higher percentages of reduction in the number of CFU counts, with percentages ranging from $97.2 \%$ to $99.7 \%$. In the MDR strains $\left(10^{5} \mathrm{CFU} / \mathrm{mL}\right)$, a significant reduction in the counting of the number of CFU in $40 \mathrm{~min}$ was observed, of S. aureus (MRSA) with a reduction of $99.99 \%$, P. aeruginosa (XDR) with $99.7 \%$, A. baumannii (PDR) with $99.5 \%$ and K. pneumoniae (KPC+) with 95.5\%.

Table 2. Count and percentage reduction in the number of CFU in ATCC (S. aureus (ATCC 6538), P. aeruginosa (ATCC 15442), S. enterica (ATCC 10708), and E. coli (ATCC 25922) strains and multidrug-resistant $S$. aureus (MRSA), P. aeruginosa (XDR), A. baumannii (PDR), and K. pneumoniae (KPC+). ATCC strains $\left(10^{5} \mathrm{CFU} / \mathrm{mL}\right)$ after exposure to ozone $(1,10,20$, 30 and $40 \mathrm{~min})$ and in bacterial suspensions of multi-resistant strains $\left(10^{5} \mathrm{CFU} / \mathrm{mL}\right)$ after exposure to ozone (40min).

\begin{tabular}{|c|c|c|c|c|c|c|}
\hline \multirow{3}{*}{$\begin{array}{c}\text { Bacterial } \\
\text { Strains }\end{array}$} & \multicolumn{6}{|c|}{ OZONE EXPOSURE TIMES } \\
\hline & \multirow[t]{2}{*}{$\mathrm{C}$} & $1^{\prime}$ & $10^{\prime}$ & $20^{\prime}$ & $30^{\prime}$ & $40^{\prime}$ \\
\hline & & \multicolumn{5}{|c|}{ Count number UFC / $\%$ of reduction } \\
\hline $\begin{array}{c}\text { S. aureus } \\
\text { (ATCC 6538) }\end{array}$ & 6287 & $123,1 / 98$ & $36 / 99,4$ & $31,9 / 99,5$ & $27,2 / 99,6$ & $20,4 / 99,7$ \\
\hline $\begin{array}{l}\text { P. aenuginosa } \\
\text { (ATCC 15442) }\end{array}$ & 3767 & $3109 / 17,5$ & $256 / 93,2$ & $105,2 / 97,2$ & $65,33 / 98,3$ & $57,8 / 98,5$ \\
\hline $\begin{array}{c}\text { S. enterica } \\
\text { (ATCC 10708) }\end{array}$ & 7391 & $711,3 / 90,4$ & $360,8 / 95,1$ & $69,7 / 99,1$ & $63,11 / 99,2$ & $53,9 / 99,3$ \\
\hline $\begin{array}{c}\text { E. coli } \\
\text { (ATCC 25922) }\end{array}$ & 3090 & $62 / 98$ & $66,1 / 98$ & $57,2 / 98,1$ & $31,2 / 99$ & $30,3 / 99$ \\
\hline $\begin{array}{l}\text { S. aureus } \\
\text { (MRSA) }\end{array}$ & 4041 & - & - & - & - & $0,1 / 99,99$ \\
\hline $\begin{array}{c}\text { P. aenuginosa } \\
\text { (XDR) }\end{array}$ & 1946 & - & - & - & - & $6,33 / 99,7$ \\
\hline $\begin{array}{l}\text { A. baumannii } \\
\text { (PDR) }\end{array}$ & 3228 & - & - & - & - & $16,6 / 99,5$ \\
\hline $\begin{array}{l}\text { K. pneumoniae } \\
\text { (KPC+) }\end{array}$ & 1894 & - & - & - & - & $86 / 95,5$ \\
\hline
\end{tabular}

C: Control not exposed to ozone; CFU: colony-forming units. 


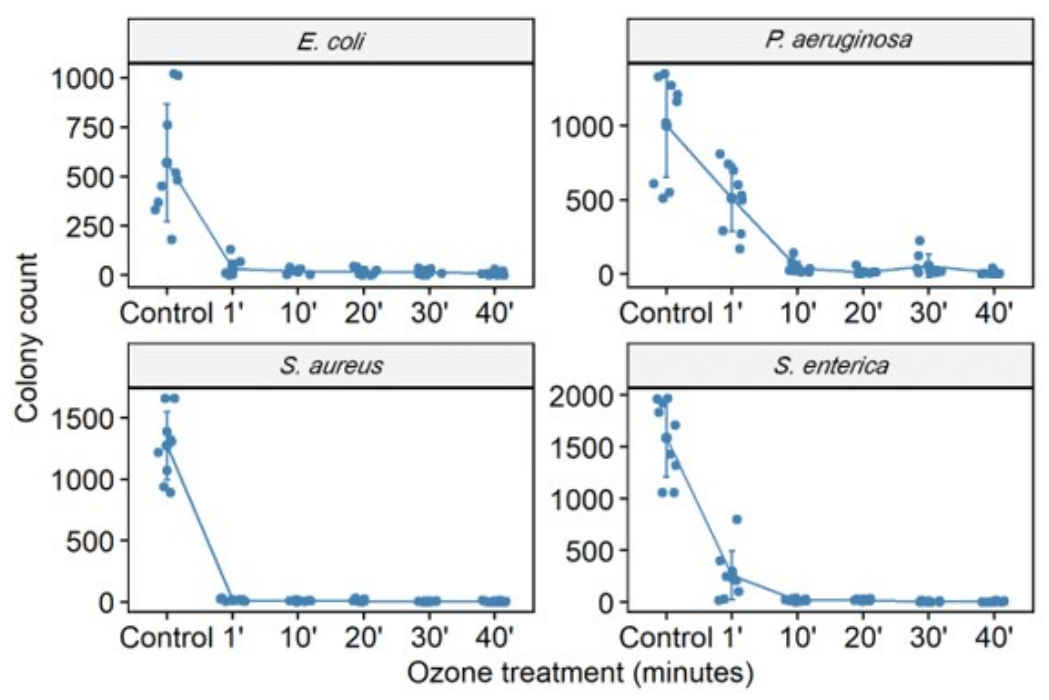

Figure 2. Counting the number of colony-forming units (CFU) in different bacterial strains (S. aureus (ATCC 6538), P. aeruginosa (ATCC 15442), S. enterica (ATCC 10708) and E. coli (ATCC 25922). number of CFU was performed in the control group (no treatment) and bacterial suspensions $\left(10^{5}\right.$ CFU/mL) after exposure to ozone for 1, 10, 20, 30, and $40 \mathrm{~min}$. 


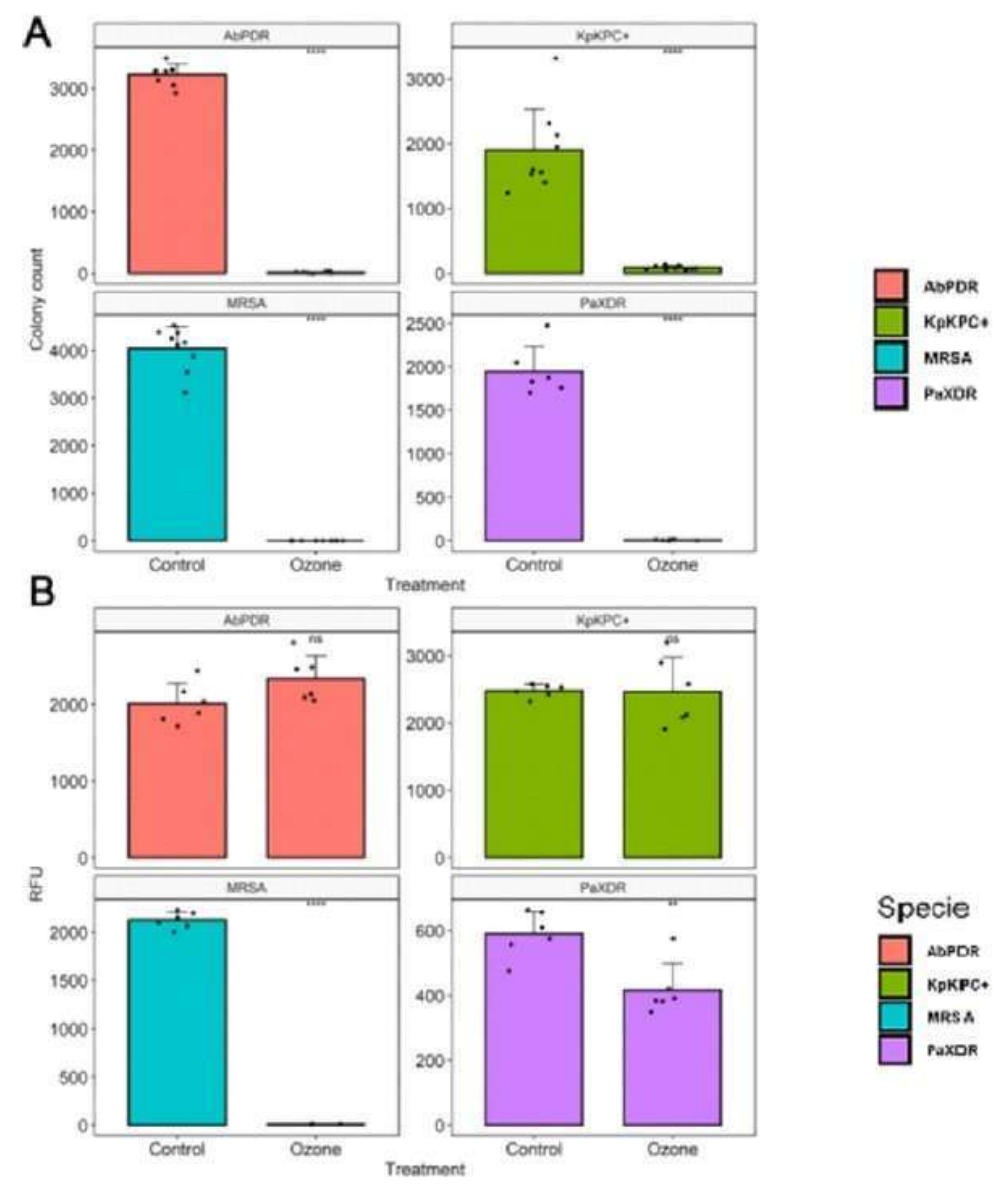

Figure 3. (A) Counting the number of colonies forming units (CFU) in different bacterial strains ( $S$. aureus (MRSA), P. aeruginosa (XDR), A. baumannii (PDR), and K. pneumoniae (KPC+)). Quantified the number of CFU in the control group (no treatment) and bacterial suspensions (105 CFU/mL) after exposure to ozone for $40 \mathrm{~min}$. (B) Analysis of cell viability after ozone treatment in different bacterial strains (S. aureus (MRSA), P. aeruginosa (XDR), A. baumannii (PDR), and K. pneumoniae (KPC+)). Performed the measurement of fluorescence intensity (Relative Fluorescence Units, RFU) after the conversion of resazurin to resofurin by viable bacteria was performed in the control group (no treatment) and bacterial suspensions $\left(10^{5} \mathrm{CFU} / \mathrm{mL}\right)$ after exposure to ozone for $40 \mathrm{~min}$. Results represent three randomly chosen colonies in the control group (no treatment) and after ozone treatment. ${ }^{* *}$ Statistically significant $(\mathrm{p}<0.01),{ }^{* * *}$ Statistically significant $(\mathrm{p}<0.001)$.

\subsection{Cell Viability}

Ozone treatment significantly reduced bacterial growth in S. aureus (MRSA), leading to an inhibition of about $99.6 \%$, followed by P. aeruginosa XDR (29.2\%) (Figure 4). All the same found no difference in bacterial viability after ozone treatment in strains of $S$. aureus (ATCC 6538), P. aeruginosa (ATCC 15442), S. enterica (ATCC 10708), E. coli (ATCC 25922), A. baumannii (PDR), and K. pneumoniae (KPC+) (Figure 3 and 4). 


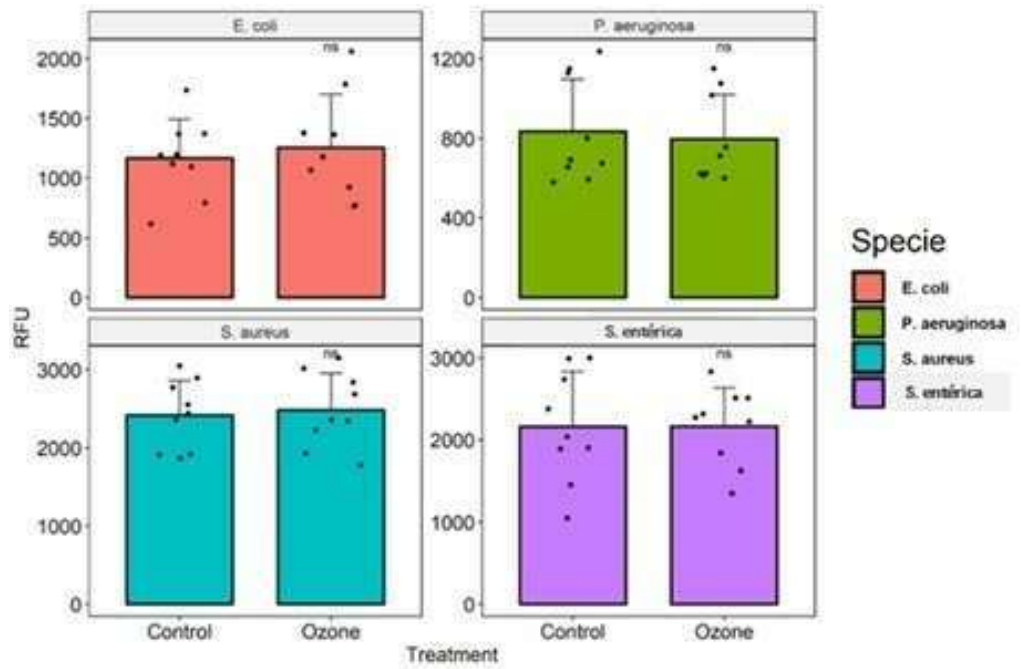

Figure 4. Analysis of cell viability after ozone treatment in different bacterial strains (S. aureus (ATCC 6538), S. enterica (ATCC 10708), E. coli (ATCC 25922), and P. aeruginosa (ATCC 15442)). Performed the measured fluorescence intensity (Relative Fluorescence Units, RFU) after the conversion of resazurin to resofurin by viable bacteria in the control group (no treatment) and bacterial suspensions $\left(10^{5} \mathrm{CFU} / \mathrm{mL}\right)$ after exposure to ozone for $40 \mathrm{~min}$. Results represent values from 3 randomly chosen colonies, in the control group (no treatment) and after treatment with ozone. ** Statistically significant $(\mathrm{p}<0.01),{ }^{* * *}$ Statistically significant $(\mathrm{p}<0.001)$.

\subsection{Scanning electron microscopy (SEM)}

Scanning electron microscopy was performed to confirm membrane damage to bacterial species. Morphological analysis showed that S. aureus (MRSA) and P. aeruginosa (XDR) present membrane alterations after $\mathrm{O}_{3}$ treatment. All bacterial controls showed smooth and homogeneous surfaces. The therapy produced some cell wall protrusions (Figure 5). 

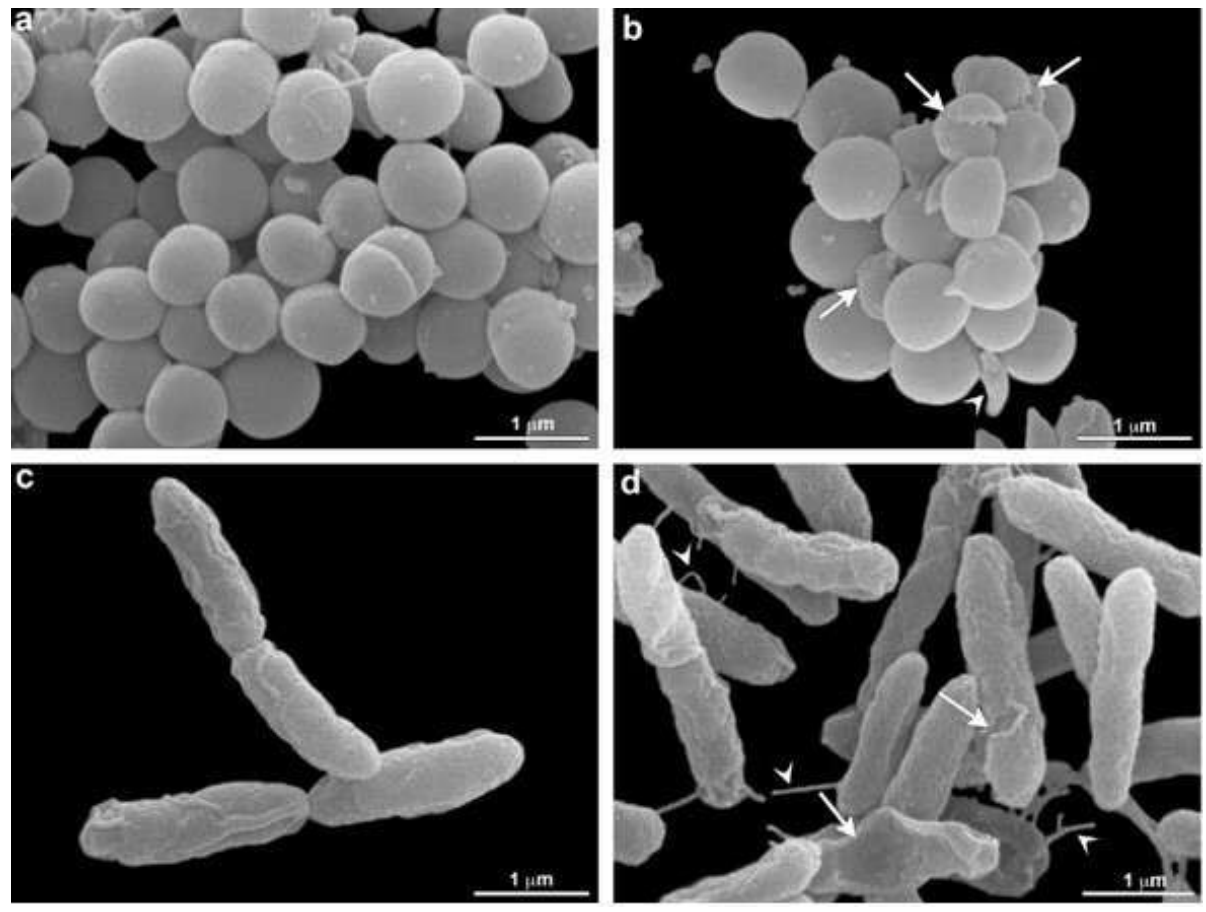

Figure 5. Morphological analysis of $\mathrm{O}_{3}$ treatment by electron microscopy. S. aureus (MRSA) (a-b) $P$. aeruginosa $(\mathrm{XDR})(\mathrm{c}-\mathrm{d})$ are seen without $(\mathrm{a}, \mathrm{c})$ and under $\mathrm{O}_{3}$ treatment $(\mathrm{b}, \mathrm{d})$. An alteration in S. aureus (MRSA) shape is seen (arrowhead) in a. Damage in bacterial is observed after treatment (arrows) (b). Note that control cells are very rounded and present a homogeneous surface (a). Damaged cells are observed after treatment in $P$. aeruginosa (XDR)(arrows) (d). Some cell wall protrusions are observed in treated cells (arrowhead) (d). Did not verify these aspects in control cells (c).

\section{Discussion}

Ozone generating equipment is already used as an easy and effective method of disinfection and sanitization to prevent the spread of MDR microorganisms in hospital wards. Furthermore, the portable characteristic of the equipment makes the mobile sanitation process viable for application in specific hospital areas [81-85]. Its high efficiency has been evaluated against many microorganisms, such as bacteria, fungi, and viruses both on the surface and suspended in the air [86], and, for this reason, it has also been validated by several international organizations [87]. The practical applicability of ozone gas in the hospital environment can improve the microbiological condition, preventing and contributing to reducing HAI rates. For this reason, in this in vitro study, we used gaseous ozone, which has greater disinfectant capacity due to its distribution and uniform penetration. Thus, we can inactivate microorganisms that may be present both on the surfaces and under the covers of hospital furniture [43, 51].

Although few studies have investigated the relationship between ozone concentration and the microclimate conditions of different environments [88], some experiments have demonstrated that ozone concentration and relative humidity values played an important role in ozone efficiency and antimicrobial effect [89]. Humidity is an important parameter and must be considered because, in arid environmental conditions, 
the disinfection procedure may require a considerably longer exposure time. In addition, microorganisms die more quickly with increasing humidity, which favors the formation of free radicals [89]. Hudson and colleagues evaluated the effect of concentration, exposure time, and relative humidity in a study using 12 viruses. The results of this work showed a reduction of three orders of magnitude, concerning the initial virus titer, at a concentration of 25 ppm of ozone per $15 \mathrm{~min}$ of exposure to $>90 \% \mathrm{RH}$ [90]. The results of another study suggested that ozone sterilization was more effective with no air movement (no fans) at low temperature and humidity than at high temperature and humidity [91]. Finally, though, a recent study analyzed the influence of microclimate on the effectiveness of ozone indoors, showing that different temperature conditions, relative humidity, and distance from the ozone generator did not reduce microbial load [51]. The current study's parameters were satisfactory, with relative humidity ranging from $71.4 \% \mathrm{RH}$ to $77.2 \% \mathrm{RH}$ and an average temperature around $23.4^{\circ} \mathrm{C}$.

The total ozone dose has been considered an essential factor for biocidal activity and is calculated as the product of exposure time and concentration [92]. In 2008, Tseng and $\mathrm{Li}$ [93] reported that the ozone dosage required for $99 \%$ viral inactivation should be calculated as ppm $\times$ min (i.e., a product of the ozone gas concentration multiplied by the duration), obtaining a value of $114 \mathrm{~min}$ [ppm] at 55\% relative humidity to inactivate the dsDNA virus (T7). Although it has not tested the antiviral action on pathogenic viruses or their substitutes, the study by Pironti et al. [51] evaluated the effectiveness of ozone in a Gram-negative bacteria used as an indicator of microbial contamination. Value of $112 \mathrm{~min}$ [ppm] by calculating the mean concentration $(1.6 \mathrm{ppm})$ and the exposure time $(70 \mathrm{~min})$, which was very close to that suggested by others to inactivate the viruses, were obtained [93]. As stated in the literature, the critical factor for the inactivation of microorganisms in the total ozone dose, which is calculated as the product of the exposure time and the concentration, however, if we consider this calculation, our values will be higher, as we use higher ozone concentrations and exposure times with large variation intervals (10 in $10 \mathrm{~min})$. According to our measurements, the average concentration of ozone recorded reached $43.9 \mathrm{ppm}$, reaching the minimum average value of $21.1 \mathrm{ppm}$ and the maximum average value of $71.1 \mathrm{ppm}$, with complete disappearance of the ozone after $30 \mathrm{~min}$. Short exposure time to ozone was able to interfere with bacterial growth, showing that in $1 \mathrm{~min}$, ozone inhibited colony growth by $90 \%(1 \log 10)$ for S. enterica ATCC 10708, 98\% $(\sim 2 \log 10)$ for S. aureus ATCC 6538, and E. coli ATCC 25922, respectively. P. aeruginosa ATCC 15442 was an exception, showing an inhibition rate of $17.5 \%$ with 1 min of exposure to ozone. Conversely, at $10 \mathrm{~min}$ of exposure, its bacterial growth inhibition rate increased to approximately 95\%. After exposure to ozone for $10 \mathrm{~min}$, S. aureus ATCC 6538 showed a reduced rate in colony growth $(\mathrm{CFU} / \mathrm{mL})$ around 99\% (2 $\log 10)$. Verified the same for $S$. enterica (ATCC 10708) at $20 \mathrm{~min}$ and E. coli ATCC 25922 at $30 \mathrm{~min}$. The longest exposure time used in this study was $40 \mathrm{~min}$, and among the ATCC strains tested, $P$. aeruginosa ATCC 15442, despite a high value, was the lowest rate of reduction in colony growth $(98.5 \%)$ in comparison to others. In the MDR strains of the ESKAPE group, ozone was able to reduce the increase by $99.99 \%$ ( $3 \log 10)$ of the colonies, followed by P. aeruginosa (XDR) 
with 99.7\% ( 3 $\log 10)$, A. baumannii (PDR) with (99.5\%) and K. pneumoniae (KPC+) with 95.5\% ( 1.5 $\log 10)$. Our results agree with previous studies that demonstrated a reduction in colony number $(\mathrm{CFU} / \mathrm{mL})$ by around three $\log 10$ in bacteria known to cause hospitalacquired infections [94-96]. One of the studies used an ozone dose of 25 ppm for $20 \mathrm{~min}$, with a short period of excess moisture (90\% RH), and was able to inactivate more than 3 $\log 10$ in most bacteria, including A. baumannii, Clostridium difficile, and methicillinresistant $S$. aureus, both in a laboratory test system and under simulated field conditions [94]. Another study obtained the same reduction by applying the exact ozone dosage at different exposure times and 75-95\% [96]. According to Moat et al., the increase in ozone concentration can lead to disinfectant efficacy [95]. Zoutman et al. showed that it could only achieve a greater than six log 10 reduction for MRSA at an ozone concentration of 500 ppm (exposure time $90 \mathrm{~min}$ ) at a relative humidity of $80 \%$, produced by a separate humidifier [97].

Reduced cell viability is one of the highly reliable biomarkers of cytotoxicity [98]. Several tests allow evaluating cell viability after a toxicity study in cultured cells. In our study, the method used to assess cell viability was the Resazurin Reduction Assay, one of the most frequently used tests for this type of assessment. Resazurin (7-Hydroxy-3Hphenoxazin-3-one 10-oxide) is a redox dye used as an indicator of metabolic activity in cell cultures and has numerous applications, such as toxicity, proliferation, and cell viability studies [99]. Resazurin is a non-fluorescent blue reagent that, by the action of the dehydrogenase enzyme found in metabolically active cells, is reduced to resorufin, which is highly fluorescent and has a pink color. This conversion only occurs in viable cells, and as such, the amount of resorufin produced is proportional to the number of viable cells in the sample [99]. Resazurin is not toxic to cells, and the occurrence of cell death is not necessary to obtain the measurements, being a simple and fast test, which can be measured either by colorimetry or by fluorimetry [100], and the amount of resorufin produced is proportional to the number of viable cells [101]. According to our results, we observed that ozone significantly reduced the in vitro growth of bacteria.

Conversely, when we investigated its metabolic capacity through resazurin, we found a significant reduction in values only for two strains, showing that ozone was able to interfere with cell viability of S. aureus (MRSA), which showed inhibition of about 99.6\%, followed by P. aeruginosa XDR (29.2\%). Curiously, in a recent study using the same strains, we have shown that ozone at low concentrations did not interfere with bacterial growth, but it could significantly inhibit cell viability [102]. Interestingly, reference strains (ATCC) from all species were less susceptible to ozone treatment. Similarly, a study demonstrated that antibiotic resistance of the isolates was not correlated to higher ozone tolerance [103]. Increased susceptibility of PaXDR and MRSA to ozone may be due to a metabolic cost associated with antibiotic resistance that decreased fitness and reduced ecological versatility of resistant strains [104]

Although not as pronounced, the effectiveness of ozone as a disinfectant varies significantly between different types of bacteria, even at the strain level $[105,106]$, and depends on several factors such as growth stage, cell envelope, the efficiency of repair 
mechanisms, and the type of viability indicator used [107-109]. In addition, some factors can reduce the ozone stability or can protect microorganisms from its effects, thus decreasing the efficiency of disinfection, such as concentration and type of dissolved organic material or the presence of flakes or particles [110-112]. Yet, ozone decomposition results in superoxide radicals, hydroperoxyl radicals, and hydroxyl radicals [113,114]. Microorganisms, through detoxification enzymes, can develop mechanisms such as the production of superoxide dismutases, reductases, peroxides, and catalases to neutralize the lethal effects of reactive oxygen species $[75,115,116]$. In E. coli, two of these mechanisms $($ SoxR and $O x y R)$ responsive redox transcription regulators have already been well described [117]. Both regulators are induced in the presence of radicals [118] and activate several genes such as soxS and sod, which, in turn, protect against these radicals through DNA repair or removal of the radicals [117]. DnaK and RpoS are two general stress gene regulators which, although not dedicated mechanisms of protection against oxidative radicals, have previously been shown to confer protection against them [119-121]. $S$. aureus uses the expression of several of these detoxification proteins, including the catalase $(k a t A)$, superoxide dismutase $(\operatorname{sod} A, \operatorname{sod} M)$, thioredoxin reductase $(\operatorname{tr} x B)$, thioredoxin $(\operatorname{tr} x A)$, alkyl hydroperoxide reductase $(a h p C, a h p F)$ enzymes) and glutathione peroxidase $(g p x A)$ [122]. Similar radicals are produced during ozone treatments, and therefore these genes are expected to play an important role in protecting cells against this technology in different bacteria that could also justify interfering with cell viability.

The disinfectant potential of ozone is attributed to its ability to promote cell wall disturbance extravasation of ions and intracellular molecules, triggering cell death [122]. The primary cellular targets for ozone are nucleic acids, where damage can range from base lesions to single and double-strand breaks [106]. Lesions can lead to more or less compromising point mutations, whereas massive DNA breakage is lethal if not repaired [122-125]. Many studies provide evidence that the cell envelope is also affected during ozonation, probably even before severe DNA damage occurs [126-128]. Ozone can influence the global polarity of the bacterial surface [75], involving mechanisms of lipid peroxidation $[129,130]$ and degradation of transmembrane proteins that control the flow of ions. As a result, the cells will rupture with subsequent leakage of ions between the media, resulting in the death of the microorganism [78]. In addition, the high oxidative potential of ozone contributes to changes in the zeta potential. A physical property is applied to assessing the degree of peripheral electronegativity on the cell surface when suspended in a fluid [131]. In the study by Feng et al. (2018), as the ozone dose increases, the zeta potential tends to decrease, becoming hostile and causing greater bacterial instability in the medium [75,132]. Ozone is a gas that can oxidize glycoproteins, glycolipids, and cell wall amino acids, destroying sulfhydryl groups in enzymes, causing the breakdown of cell enzymatic activity [133,134].

Our study expands and corroborates what is already known about the gas since the analysis of the inhibition of microbial growth and/or reduction of the CFU count in plates exposed to ozone, containing both reference strains and clinical and environmental strains highly resistant to antimicrobials, compared to the control group, proved its effectiveness 
as a chemical compound in microbial control processes. The practical applicability of gaseous ozone in hospital environments can improve the microbiological condition, preventing and contributing to HAI rates. It is exciting and unprecedented evidence of the potential for ozone disinfection because, in natural indoor environments, it is possible to disinfect surfaces not typically disinfected with hand-applied liquid disinfectants. In this sense, it can eliminate MDR organisms with a significant advantage compared to mechanical disinfection methods with liquid disinfectants of environmental surfaces in Health Care Establishments, including the hospital environment, where it is common to use other chemical compounds in liquid form.

\section{Conclusions}

HAIs represent the most common adverse event in ICUs and are usually caused by MDR bacteria. As a result, preventing the transmission of MDR bacteria has become increasingly important to limit the spread of these infections. Given the prolonged hospital stays and increased treatment costs seen in patients who develop HAIs, ozonebased decontamination approaches may represent the future of hospital cleaning methods as a highly cost-effective and promising intervention capable of being used as an additional procedure for terminal cleaning, in addition to the "classic" terminal cleaning (by current biocides). Our results evidenced the antimicrobial potential of gaseous ozone in bacteria that are currently a significant problem worldwide. In the future, this resource will possibly compose the protocols for disinfection of hospital environments and surfaces, ensuring the control of microbial development.

Supplementary Materials: The following supporting information can be downloaded at: www.mdpi.com/xxx/s1, Figure S1. SANITECH O3-80-Sanitization equipment ozone generator coupled to two containers of approximately $1 \mathrm{~m}^{3}$ each, used for exposing samples to ozone.

Author Contributions: Conceptualization, KR; formal analysis, KR, GCL, VM, FOC, and JPRSC; data curation, MHSVB; writing - review and editing, KR, S.G.D-S.; visualization, KR, and S.G.D-S.; supervision, KR; funding acquisition, S.G.D-S. All authors have read and agreed to the published version of the manuscript.

Funding: This research was funded by the Carlos Chagas Filho Foundation for Research Support of the State of Rio de Janeiro (FAPERJ n ${ }^{\circ}$ E-26 110.198-13; E26 202.841-2018) and the Brazilian Council for Scientific Research (CNPq-nº 467.488.2014-2; 3075732011;3013322015-0).

Institutional Review Board Statement: Not applicable.

Informed Consent Statement: Not applicable.

Data Availability Statement: The data presented in this study are available on request from the corresponding author

Acknowledgments: The Electron microscopy platform Rudolf Barth from Oswaldo Cruz Institute/FIOCRUZ for electron microscopy analysis facilities. K.R. and G.C.L. are Post-doc fellows from CAPES/CDTS and CNPq. JPRS is a CAPES/MSci fellow from the Science and Biotechnology Post Graduation program of the Federal Fluminense University. 
Conflicts of Interest: The authors declare no conflict of interest.

\section{References}

1. Allegranzi, B.; Bagheri Nejad, S.; Combescure, C.; Graafmans, W.; Attar, H.; Donaldson, L.; Pittet, D. Burden of endemic healthcare-associated infection in developing countries: systematic review and meta-analysis. Lancet. 2011, 337, 228-41. doi: 10.1016/S0 140-6736(10)61458-4.

2. ECDC. European Centre for Disease Prevention and Control Annual epidemiological report 2016 -healthcare-associated infections acquired in intensive care units. 2017. Available online: https://www.ecdc.Euro pa.eu/en/publications-data/healthcare-associatedinfections-intensive-care-units-annualepide miological-0. Accessed on 20 August 2021.

3. Brasil. Boletim Segurança do Paciente e Qualidade em Serviços de Saúde n 16: Avaliação dos indicadores nacionais das Infecções Relacionadas à Assistência à Saúde (IRAS) e Resistência microbiana do ano de 2016. 2017. Available online: https://www20.Anvisa.gov.br/segura ncadopaciente/ index.php/ publicacoes/item/boletim-seguranca-do-paciente-e-qualidadeem-servicos-de-saude-n-16-avaliacao dos-indicadores-nacionais-das-infeccoes-relacionadas-a-assistencia-a-saudeiras-e-resisten cia microbiana-do-ano-de-2016. Acessed on 20 August 2021.

4. Jenks, J.; Duse, A.; Wattal, C.; Zaidi, A.K.; Wertheim, H.F.; Sumpradit, N.; Vlieghe, E.; Hara, G.L.; Gould, I.M.; Goossens, H.; Greko, C.; So, A.D.; Bigdeli, M.; Tomson, G.; Woodhouse, W.; Ombaka, E.; Peralta, A.Q.; Qamar, F.N.; Mir, F.; Kariuki, S.; Bhutta, Z.A.; Coates, A.; Bergstrom, R.; Wright, G.D.; Brown, E.D.; Cars, O. Antibiotic resistance needs global solutions. Lancet Infect Dis. 2014; 14:550. doi: 10.1016/S1473-3099(13)70318-9.

5. WHO. World Health Organization. The burden of healthcare-associated infection worldwide: a summary. World Heal Organ. 2011; 3. Available online: http:// www.who.int/gpsc/coun trywork/summary2010 0430 en.pdf. Accessed on 20 August 2021.

6. Ali, S.; Birhane, M.; Bekele, S.; Kibru, G., Teshager, L.; Yilma, Y.; Ahmed, Y.; Fentahun, N.; Assefa, H.; Gashaw, M.; Gudina, E.K. Healthcare-associated infection and its risk factors among patients admitted to a tertiary hospital in Ethiopia: a longitudinal study. Antimicrob. Resist. Infect. Control. 2018, 7, 2. doi: 10.1186/s13756-017-0298-5.

7. Umscheid C.; Mitchell, M.D.; Doshi, J.A.; Agarwal, R.; Williams, K.; Brennan, P.J. Estimating the proportion of healthcareassociated infections that are reasonably preventable and the associated mortality and costs. Infect. Control Hosp. Epidemiol. 2011, 32, 101-114. doi: 10.1086/657912.

8. Gatt, Y.E.; Margalit, H. Common adaptive strategies underlie within-host evolution of bacterial pathogens. Mo.l Biol. Evol. 2021, 38, 1101-1121. doi: 10.1093/molbev/msaa278.

9. Santajit, S.; Indrawattana, N. Mechanisms of antimicrobial resistance in ESKAPE pathogens. Biomed. Res. Int. 2016, $2016,2475067$. doi: 10.1155/2016/2475067.

10. Georgescu, M.; Gheorghe, I.; Curutiu, C.; Lazar, V.; Bleotu, C.; Chifiriuc, M.C. Virulence and resistance features of Pseudomonas aeruginosa strains isolated from chronic leg ulcers. BMC Infect Dis. 2016, 16, 92. doi: 10.1186/s12879-016-1396-3.

11. Coelho, F.; Coelho, M.; Diniz, A.; Vicente, G.; Vieira, C. Velhos Problemas, novos desafios. Rev Tecn Hospitalar. 2011; 43:30-32.

12. Tadesse, B.T.; Ashley, E.A.; Ongarello, S.; Havumaki, J.; Wijegoonewardena, M.; Gonzalez, I.J.; Dittrich, S. Antimicrobial resistance in Africa: a systematic review. BMC Infectious Diseases. 2017, 17, 616. doi:10.1186/s12879-017-2713-1

13. Gajdács, M.; Albericio, F. Antibiotic resistance: from the bench to patients. Antibiotics (Basel). 2019, 8, 129. doi: 10.3390/antibiotics8030129.

14. Bocé M,; Tassé M,; Mallet-Ladeira S,; Pillet F,; Da Silva C,; Vicendo P,; Lacroix PG,; Malfant I,; Rols MP. Effect of trans(NO, OH)$[\mathrm{RuFT}(\mathrm{Cl})(\mathrm{OH}) \mathrm{NO}](\mathrm{PF}(6))$ ruthenium nitrosyl complex on methicillin-resistant Staphylococcus epidermidis. Sci Rep. 2019, 9, 4867. doi: 10.1038/s41598-019-41222-0.

15. Andersen, K.G.; Rambaut, A.; Lipkin, W.I.; Holmes, E.C.; Garry, R.F. The proximal origin of SARS-CoV-2. Nat Med. 2020, 26, 450-452. doi: 10.1038/s41591-020-0820-9. 
16. Park, S.E. Epidemiology, virology, and clinical features of severe acute respiratory syndrome -coronavirus-2 (SARS-CoV-2; Coronavirus Disease-19). Clin. Exp. Pediatr. 2020, 63, 119-124. doi: 10. 3345/cep.2020.00493.

17. WHO. World Health Organization. Coronavirus disease (COVID-19) pandemic. WHO, 2020. Available online: https://www.who.int/emergencies/diseases/novel-coronavirus-2019. Accessed on 20 August 2021.

18. Zhu, N.; Zhang.; D.; Wang, W.; Li, X.; Yang, B.; Song, J.; Zhao, X.; Huang, B.; Shi, W.; Lu, R.; Niu, P.; Zhan, F.; Ma, X.; Wang, D.; $\mathrm{Xu}, \mathrm{W}$; Wu, G.; Gao, G.F.; Tan, W. China novel coronavirus investigating and research team. A novel coronavirus from patients with pneumonia in China,, 2019. N. Engl. J. Med. 2020, 382, 727-733. doi: 10.1056/NEJMoa2001017.

19. Canto,'N.R.; Ruiz-Garbajosa, P. Co-resistance: an opportunity for the bacteria and resistance genes. Curr. Opin. Pharmacol. 2011, 11, 477-485. doi: 10.1016/j.coph.2011.07.007.

20. Clancy, C.J.; Nguyen, M.H. Coroviruses disease 2019, superinfections, and antimicrobial development. What can we expect? Clin. Infect. Dis. 2020, 71, 2736-2743. doi: 10.1093/cid/ciaa524.

21. Bengoechea, J.Á.; Bamford, C.G.G. SARS-CoV-2, bacterial co-infections, and AMR: the deadly trio in COVID-19? EMBO Mol Med. 2020, 26, e12560. doi: 10.15252/emmm.202012560.

22. Fu, Y.; Yang, Q.; Xu, M.; Kong, H.; Chen, H.; Fu, Y.; Yao, Y.; Zhou, H.; Zhou, J. Secondary bacterial infections in critical ill patients with coronavirus disease 2019. Open Forum Infect. Dis. 2020, 5, ofaa220. doi: 10.1093/ofid/ofaa220.

23. Rawson, T.M.; Moore, L.S.P.; Zhu, N.; Ranganathan, N.; Skolimowska, K.; Gilchrist, M.; Satta, G.; Cooke, G.; Holmes, A. Bacterial and fungal co-infection in individuals with coronavirus: a rapid review to support COVID-19 antimicrobial prescribing. Clin. Infect. Dis. 2020, 71, 2459-2468. doi: 10.1093/cid/ciaa530.

24. Santajit, S.; Indrawattana, N. Mechanisms of antimicrobial resistance in ESKAPE pathogens. Biomed. Res. Int. 2016, $2016,2475067$. doi: 10.1155/2016/2475067.

25. Iseppi, R.; Sabia, C.; Bondi, M.; Mariani, M.; Messi, P. Virulence factors, drug resistance and biofilm formation in pseudomonas species isolated from healthcare water systems. Curr Microbiol. 2020, 77, 1737-1745. doi: 10.1007/s00284-020-01990-9.

26. Sarshar, M.; Behzadi, P.; Scribano, D.; Palamara, A.T.; Ambrosi, C. Acinetobacter baumannii: an ancient commensal with weapons of a pathogen. Pathogens 2021, 10, 387. doi: 10.3390/pathogens 10040387.

27. Senobar Tahaei, A.S.; Stájer, A.; Barrak, I.; Ostorházi, E.; Szabó, D.; Gajdács, M. Correlation between biofilm-formation and the antibiotic-resistant phenotype in Staphylococcus aureus isolates: a laboratory-based study in Hungary and a review of the literature. Infect. Drug Resist. 2021, 14, 1155-1168. doi: 10.2147/IDR.S303992.

28. Juhász, J.; Ligeti, B.; Gajdács, M.; Makra, N.; Ostorházi, E.; Farkas, F.B.; Stercz, B.; Tóth, Á.; Domokos, J.; Pongor, S.; Szabó, D Colonization dynamics of multidrug-resistant Klebsiella pneumoniae are dictated by microbiota-cluster group behavior over individual antibiotic susceptibility: a metataxonomic analysis. Antibiotics (Basel). 2021, 10, 268. doi: 10.3390/antibi otics10030268.

29. Miller, W.R.; Munita, J.M.; Arias, C.A. Mechanisms of antibiotic resistance in enterococci. Expert Rev Anti Infect Ther. 2014; 12:12211236. doi: 10.1586/14787210.2014.956092.

30. Behzadi, P.; Baráth, Z.; Gajdács, M. It's not easy being green: a narrative review on the microbiology, virulence and therapeutic prospects of multidrug-resistant Pseudomonas aeruginosa. Antibiotics (Basel) 2021, 10, 42. doi: 10.3390/antibiotics10010042.

31. Gajdács, M.; Bátori, Z.; Ábrók, M.; Lázár, A.; Burián, K.. Characterization of resistance in gram-negative urinary isolates using existing and novel indicators of clinical relevance: a 10-year data analysis. Life (Basel). 2020, 10, 16. doi: 10.3390/life10020016.

32. Goudarzi, M.; Tayebi, Z.; Fazeli, M.; Miri, M.; Nasiri, M.J. Molecular characterization, drug resistance and virulence analysis of constitutive and inducible clindamycin resistance Staphylococcus aureus strains recovered from clinical samples, Tehran - Iran. Infect. Drug Resist. 2020, 13, 1155-1162. doi: 10.2147/IDR.S251450.

33. Munita, J.M.; Arias, C.A. Mechanisms of antibiotic resistance. Microbiol Spectr. 2016, 4, 10.11 28/mi crobiolspec.VMBF-0016-2015. doi: 10.1128/microbiolspec.VMBF-0016-2015. 
34. Miller, W.R.; Munita, J.M.; Arias, C.A. Mechanisms of antibiotic resistance in enterococci. Expert. Rev. Anti. Infect. Ther. 2014; 12:1221-1236. doi: 10.1586/14787210.2014.956092.

35. WHO. World Health Organization. Global priority list of antibiotic-resistant bacteria to guide research, discovery, and development of new antibiotics. WHO, 2017. Geneva: World Health Organization. Available online: https://www.who.int/medicines/publicati ons/WHO-PPL-Short_Summary_25 Feb-ET_NM_WHO.pdf. Accessed on 15 August 2021.

36. Magiorakos, A.P.; Srinivasan, A.; Carey, R.B.; Carmeli, Y.; Falagas, M.E.; Giske, C.G.; Harbarth, S.; Hindler, J.F.; Kahlmeter, G.; Olsson-Liljequist, B.; Paterson, D.L.; Rice, L.B.; Stelling, J.; Struelens, M.J.; Vatopoulos, A.; Weber, J.T.; Monnet, D.L. Multidrugresistant, extensively drug-resistant and pan drug-resistant bacteria: an international expert proposal for interim standard definitions for acquired resistance. Clin. Microbiol. Infect, 2012, 18, 268-281. doi: 10.1111/j.1469-0691.2011.03570.x.

37. Garner, J.S. Guideline for isolation precautions in hospitals. The hospital infection control practices advisory committee. Infect. Control Hosp. Epidemiol. 1996, 17, 54-80. doi: 10.1086/647190.

38. Oliveira, A.C. Infecções Hospitalares, Epidemiologia, Prevenção e Controle, 1rd ed.; Guanabara Koogan - Grupo Gen: Rio de Janeiro, Brazil, 2005; 710p.

39. Pelczar, M.J.; Chan, E.C.S.; Krieg, N.R. Microbiologia, conceitos e aplicações, 2rd ed.; Makron Books: São Paulo, Brazil:, 1997; 524p.

40. Fernandes, A.T.; Fernandes, M.O.V.; Ribeiro Filho, N.; Graziano, K.U.; Gabrielloni, M.C.; Cavalcante, N.J.F.; Lacerda, R.A. Infecção Hospitalar e suas interfaces na Área da Saúde, 1rd ed.; Atheneu: São Paulo, Brazil, 2000; 1795p.

41. Stephanie, J.D. Controlling hospital-acquired infection: focus on the role of the environment and new technologies for decontamination. Clin. Microbiol. Rev. 2014, 27, 665-690. doi: 10.1128/ CMR.00 020-14.

42. Gilbert, P.; McBain, A.J. Potential impact of increased use of biocides in consumer products on the prevalence of antibiotic resistance. Clin. Microbiol. Rev. 2003, 16, 189-208. doi: 10.1128/CMR.16.2. 189-208.2003.

43. Pitten, F.A.; Werner, H.P.; Kramer, A. A standardized test to assess the impact of different organic challenges on the antimicrobial activity of antiseptics. J. Hosp. Infect. 2003, 55, 108-115. doi: 10.1016/ s0195-6701(03)00260-3.

44. Brunetti, L.; Santoro, E.; Cavallo, P.; Boccia, G.; Motta, O.; Capunzo, M. Two-years surveillance of fungal contamination in three hospital departments in Campania region. J. Prev. Med. Hyg. 2006, 47, 22-25. PMID: 17061407.

45. Brunetti, L.; De Caro, F.; Boccia, G.; Cavallo, P.; Capunzo, M. Surveillance of nosocomial infections: a preliminary study on yeast carriage on hands of healthcare workers. J. Prevent. Med. Hyg. 2008; 49:63-68. PMID: 18847179.

46. Sauerbrei, A.; Schacke,M.; Glück, B.; Bust, U.; Rabenau, HF.; Wutzler, P. Does limited virucidal activity of biocides include duck hepatitis B virucidal action. BMC Infect. Dis. 2012, 12, 276. doi: 10.1186/1471-2334-12-276.

47. Motta, O.; Zarrella, I.; Cucciniello, R.; Vigliotta, G.; Proto, A. Study of the antibacterial activity in the gas phase of a chemical formulation for household waste management. Lett. Appl. Microbiol. 2015, 60, 223-228. doi: 10.1111/lam.12360.

48. Motta, O.; Zarrella, I.; Cucciniello, R.; Capunzo, M.; De Caro, F. A new strategy to control the proliferation of microorganisms in solid hospital waste and the diffusion of nosocomial infections. Infez. Med. 2018, 26, 210-215. PMID: 30246763.

49. Moccia, G.; Motta, O.; Pironti, C.; Proto, A.; Capunzo, M.; De Caro, F. An alternative approach for the decontamination of hospital settings. J. Infect. Public Health. 2020, 13, 2038-2044. doi: 10.10 16/j.jiph. 2020.09.020.

50. Amato, A.; Caggiano, M.; Amato, M.; Moccia, G.; Capunzo, M.; De Caro, F. Infection control in dental practice during the covid19 pandemic. Int. J. Environ. Res. Public. Health. 2020 17, 1-12. doi: 10.3390/ijerph17134769.

51. Pironti, C.; Motta, O.; Proto, A. Development of a new vapor phase methodology for textiles disinfection. Cleaner Engin. Technol. 2021, 4, 100170. doi: 10.1016/j.clet.2021.100170.

52. Boucher, H.W.; Talbot, G.H.; Bradley, J.S.; Edwards, J.E.; Gilbert, D.; Rice, L.B.; Scheld, M.; Spellberg, B.; Bartlett, J. Bad bugs, no drugs: no ESKAPE! An update from the Infectious Diseases Society of America. Clin. Infect. Dis. 2009, 48, 1-12. doi: 10.1086/595011. 
53. Martinelli, M.; Giovannangeli, F.; Rotunno, S.; Trombetta, C.M.; Montomoli, E. Water and air ozone treatment as an alternative sanitizing technology. J. Prev. Med. Hyg. 2017, 58, E48-E52. PMID:28515631.

54. Nascente, E.P.; Chagas, S.R.; Pessoa, A.V.C.; Matos, M.P.C.; Andrade, M.A.; Pascoal, L.M. Potencial antimicrobiano do ozônio: aplicações e perspectivas em medicina veterinária. Pubvet. 2019,13, 130. https://doi.org/10.31533/pubvet.v13n9a412.1-14.

55. Bocci, V. Ozone: a new medical drug, 2rd.; Springer: Berlin, Germany, 2010; 336p. doi: 10.1007/978-90-481-9234-2.

56. Pandiselvam, R.; Subhashini, S.; Banuu Priya, E.P.; Kothakota, A.; Ramesh, S.V.; Shahir, S. Ozone-based food preservation: a promising green technology for enhanced food safety. Ozone: Sci. Engineering 2018, 41,17-34. doi: 10.1080/01919512. 2018.1490636.

57. Chys, M.; Demeestere, K.; Nopens, I.; Audenaert, W.T.M.; Van Hulle, S.W.H. Municipal wastewater effluent characterization, and variability analysis in view of an ozone dose control strategy during tertiary treatment: The status in Belgium. Sci. Total Environmental 2018, 625, 1198-1207. doi: 10.1016/j.scitotenv.2018.01.032.

58. Constantin, T.; Birtoiu, I.A. Preliminary study on ozone therapy in postpartum endometritis of dairy cows. Agricult. Agricul. Sci. Procedia 2016, 10, 384-389. doi:10.1016/j.aaspro.20 16.09.078.

59. Al jibouri, A.K.H.; Wu, J.; Upreti, S.R. Application of mass balance models in the process of ozone removal of naphthenic acids from water. Canad. J. Chem. Engineer. 2017, 95, 39-45. doi: 10.10 02/cjce.22638.

60. Hansen, K.M.; Spiliotopoulou, A.; Chhetri, R.K.; Casas, M.E.; Bester, K.; Andersen, H.R. Ozonation for source treatment of pharmaceuticals in hospital wastewater-ozone lifetime and required ozone dose. Chem. Eng. J. 2016, 290, 507-514. doi: 10.1016/j.cej.2016.01.027.

61. Canada, M.L.M; Abelan, U.S.; Zangaro, R.A.; Kozusny-Andreani, D.I.; Yamazaki, R.F.C.; Effectiveness of ozonated water in the reprocessing of blood dialyzers. Rev. Bras. Eng. Bioméd. 2014, 30, 215-219. doi: 10.1590/rbeb.2014.021.

62. Garcia, C.A.; Stanziola, L.; Vieira, I.S.; Naves, J.H.F.F.; Neves, S.M.N. Ozone gas in the decontamination of surgical environments. Vet. Not. 2008, 14, 37- 40.

63. Sancakli, H.S.; Siso, S.H.; Yildiz, S.O.; Gökçe, Y.B. Antibacterial effect of surface pretreatment techniques against Streptococcus mutans. Niger J. Clin. Pract. 2018, 21, 170-175. doi: 10.4103/njcp. njcp_98_16.

64. Merks, P.; Religioni, U.; Bilmin, K.; Bogusz, J.; Juszczyk, G.; Barańska, A.; Kuthan, R.; Drelich, E.; Jakubowska, M.; Świeczkowski, D.; Białoszewski, A.; Jaguszewski, M.; Panford-Quainoo, E.; Vaillancourt, R.; Białoszewski, D. Ozone disinfection of community pharmacies during the COVID-19 pandemic as a possible preventive measure for infection spread. Med Pr. 2021, 72, 529-534. doi: 10.13075/mp.5893.01091. PMID: 34140707.

65. Franke, G.; Knobling, B.; Brill, F.H.; Becker, B.; Klupp, E.M.; Belmar Campos, C.; Pfefferle, S.; Lütgehetmann, M.; Knobloch, J.K. An automated room disinfection system using ozone is highly active against surrogates for SARS-CoV-2. J. Hosp. Infect. 2021, 112, 108-113. doi: 10.1016/j.jhin. 2021.04.007.

66. Steinmann, J.; Burkard, T.; Becker, B.; Paulmann, D.; Todt, D.; Bischoff, B.; Steinmann, E.; Brill FHH. Virucidal efficacy of an ozonegenerating system for automated room disinfection. J. Hosp. Infect. 2021, 116, 16-20. doi: 10.1016/j.jhin.2021.06.004.

67. Percivalle, E.; Clerici, M.; Cassaniti, I.; Vecchio Nepita, E.; Marchese, P.; Olivati, D.; Catelli, C.; Berri, A.; Baldanti, F.; Marone, P.; Bruno, R.; Triarico, A.; Lago, P. SARS-CoV-2 viability on different surfaces after gaseous ozone treatment: a preliminary evaluation. J. Hosp. Infect. 2021, 110, 33-36. doi: 10.1016/j.jhin.2021.01.014.

68. Sundararajan, G.; Isaac, P.J.; Andal, V.; Lakshmipathy, R. Alternative therapies for Covid-19. Mater Today Proc. 2021, August 5. doi: 10.1016/j.matpr.2021.07.501.

69. Radvar, S.; Karkon-Shayan, S.; Motamed-Sanaye, A., Majidi, M.; Hajebrahimi, S.; Taleschian-Tabrizi, N.; Pashazadeh, F.; Sahebkar, A. Using ozone therapy as an option for treatment of COVID-19 Patients: A scoping review. Adv. Exp. Med. Biol. 2021, 1327, 151160. doi: 10.1007/978-3-030-71697-4_12. 
70. Chirumbolo, S.; Valdenassi, L.; Simonetti, V.; Bertossi, D.; Ricevuti, G.; Franzini, M.; Pandolfi, S. Insights on the mechanisms of action of ozone in the medical therapy against COVID-19. Int. Immunopharmacol. 2021, 96, 107777. doi: 10.1016/j.intimp.2021.107 777 .

71. Brodowska, A.J.; Nowak, A.; Śmigielski, K. Ozone in the food industry: Principles of ozone treatment, mechanisms of action, and applications: An overview. Crit Rev Food Sci Nutr. 2018, 58, 2176-2201. doi: 10.1080/10408398.2017.1308313

72. Cullen, P.J.; Tiwarib, B.K.; O'Donnell, C.P.; Muthukumarappan, K. Modelling approaches to ozone processing of liquid foods. Trends Food Sci Technol. 2009, 20, 125-136. https://doi.org/10.10 16/j.tifs.2009.01.049.

73. Kim, J.; Yousef, A.E.; Dave, S. Application of ozone for enhancing the microbiological safety and quality of foods: a review. J. Food Prot. 1999, 62, 1071-1087. doi: 10.4315/0362-028x-62.9.1071.

74. Zhang, Y.; Wu, Q.; Jumei Zhang, Z.; Yang,X. Alteration in Escherichia coli and Streptococcus faecalis cells induced by ozone. J. Food Sci. Technol. 2016, 1,106-112. doi: 10.251 77/JFST.1.3.4.

75. Feng, L.; Zhang, K.; Gao, M.; Shi, C.; Ge, C.; Qu, D.; Zhu, J.; Shi, Y.; Han, J. Inactivation of Vibrio parahaemolyticus by aqueous ozone. J. Microbiol. Biotechnol. 2018, 28, 1233-1246. doi: 10.4014/jmb. 1801.01056.

76. Han, L.; Patil, S.; Boehm, D.; Milosavljević, V.; Cullen, P.J.; Bourke, P. Mechanisms of inactivation by high-voltage atmospheric cold plasma differ for Escherichia coli and Staphylococcus aureus. Appl. Environm. Microbiol. 2016, 82,450-458. doi: 10.1128/AEM.02 660-15.

77. Ersoy, Z.G.; Barisci, S.; Turkay, O. Mechanisms of the Escherichia coli and Enterococcus faecalis inactivation by ozone. Food Sci. Technol. 2019, 100, 306-313. Doi: 10.1016/j.lwt.2018.10. 095.

78. Zhang, Y.Q.; Wu, Q.P.; Zhang, J.M.; Yang, X.H. Effects of ozone on membrane permeability and ultrastructure in Pseudomonas aeruginosa. J. Appl. Microbiol. 2011, 111, 1006-1015. doi: 10.1111/ j.13 65-2672.2011.05113.x.

79. Tomasino, S. Disinfectants. In: Official Methods of Analysis. 19 ${ }^{\text {th }}$ ed. Association of Official Analytical Chemists, cap. 6, 2012.

80. Manual Da Qualidade. Método Da Diluição De Uso. Rev. 10. In: MANUAL da Qualidade. Rio de Janeiro: INCQS/FIOCRUZ, 2013. Section 10. 21 p. (65.3210.007 review 10).

81. Food and drug administration (FDA), Generally recognized as safe (GRAS) status of ozone. 21 CFR Part 184. Fed Regist. 1982, 47, 50209-50210.

82. Knobler, S.; Mahmoud, A.; Lemon, S.; Mack, A.; Sivitz, L.; Oberholtzer, K.; editors. Institute of Medicine (US) Forum on Microbial Threats. Learning from SARS: Preparing for the Next Disease Outbreak: Workshop Summary. Washington, DC: The National Academies Press (US); 2004, 376p. doi: 10.17226/10915. PMID: 22553895.

83. Sousa, C.S.; Torres, L.M.; Azevedo, M.P.F.; Camargo, T.C.; Graziano, K.U.; Lacerda, R.A.; R.N.T. Sterilization with ozone in health care: an integrative literature review. Rev. Esc. Enfer. U.S.P. 2011, 45, 1243-1249. doi: 10.1590/s0080-62342011000500030.

84. Rubio-Romero, J.C.; Pardo-Ferreira, M.D.C.; Torrecilla-García, J.A.; Calero-Castro, S. Disposable masks: Disinfection and sterilization for reuse, and non-certified manufacturing, in the face of shortages during the COVID-19 pandemic. Saf Sci. 2020,129, 104830. doi: 10.1016/j.ssci.2020.104830.

85. Moccia, G.; De Caro, F.; Pironti, C.; Boccia, G.; Capunzo, M.; Borrelli, A.; Motta, O. Development and improvement of an effective method for air and surfaces disinfection with ozone gas as a decontaminating agent. Medicina. 2020, 56, 578. doi: 10.3390/medicine 56110578.

86. Dubuis, M.E.; Dumont-Leblond, N.; Laliberté, C.; Veillette, M.; Turgeon, N.; Jean, J.; Duchaine, C. Ozone efficacy for the control of airborne viruses: Bacteriophage and norovirus models. PLoS One 2020, 15, e0231164. doi: 10.1371/journal.pone.0231164.

87. EPA. Environmental Protection Agency. Integrated science assessment for ozone and related photochemical oxidant (Final Report, Apr 2020). 2020. Available online: https://cfpub.epa.gov/ncea/isa/recordisplay.cfm?deid=348522. Accessed on 15 August 2021.

88. Blanco, A.; Ojembarrena, F.B.; Clavo, B.; Negro, C. Ozone potential to fight against SAR-COV-2 pandemic: facts and research needs. Environ. Sci. Pollut. Res. Int. 2021, 28, 16517-16531. doi: 10. 1007/s11356-020-12036-9. 
89. Grignani E.; Mansi, A.; Cabella, R.; Castellano.;. P.; Tirabasso, A.; Sisto, R.; Spagnoli, M.; Fabrizi, G.; Frigerio, F.; Tranfo, G. Safe and effective use of ozone as air and surface disinfectant in the conjuncture of Covid-19. Gases 2021;1:19-32. doi: 10.3390/gases1010002.

90. Hudson, J.B.; Sharma, M.; Vimalanathan, S. Development of a practical method for using ozone gas as a virus decontaminating agent. Ozone Sci. Eng. 2009, 31, 216-223. doi: 10.1080/ 01919510902747969.

91. McClurkin, J.D.; Maier, D.E.; Ileleji, K.E. Half-life time of ozone as a function of air movement and conditions in a sealed container. J. Stored Prod. Res. 2013, 55, 41-47. doi: 10.1016/j. jspr.2013.07.006.

92. Dennis, R.; Cashion, A.; Emanuel, S.; Hubbard, D. Ozone gas: scientific justification and practical guidelines for improvised disinfection using consumer-grade ozone generators and plastic storage boxes. J. Sci. Med. 2020, 2, 1-15. doi: 10.37714/JOSAM. V2I1.35.

93. Tseng, C.; Li, C. Inactivation of surface viruses by gaseous ozone. J. Environ. Health. 2008, 70, 56-63. PMID: 18561570.

94. Sharma, M.; Hudson, J.B. Ozone gas is an effective and practical antibacterial agent. Am. J. Infect. Control. 2008, 36, 559-563. doi: 10.1016/j.ajic.2007.10.021.

95. Moat, J.; Cargill, J.; Shone, J.; Upton, M. Application of a novel decontamination process using gaseous ozone. Canad. J. Microbiol. 2009, 55, 928-933. doi: 10.1139/w09-046.

96. Knobling, B.; Franke, G.; Klupp, E.M.; Belmar Campos, C.; Knobloch, J.K. Evaluation of the effectiveness of two automated room decontamination devices under real-life conditions. Front. Public Health. 2021, 9, 618263. doi: 10.3389/fpubh.2021.618263.

97. Zoutman, D.; Shannon, M.; Mandel, A. Effectiveness of a novel ozone-based system for the rapid high-level disinfection of health care spaces and surfaces. Am. J. Infect. Control. 2011, 39, 873-879. doi: 10.1016/j.ajic.2011.01.012.

98. Xu, Y.; Ji, J.; Wu, H.; Pi, F.; Blaženović, I.; Zhang, Y.; Sun, X. Untargeted GC-TOFMS-based cellular metabolism analysis to evaluate ozone degradation effect of deoxynivalenol. Toxicon 2019, 168, 49-57. doi: 10.1016/j.toxicon.2019.06.022.

99. Präbst, K.; Engelhardt, H.;Ringgeler, S.; Hübner, H. Basic Colorimetric Proliferation Assays: MTT, WST, and Resazurin. Methods Mol Biol. 2017,1601, 1-17. doi: 10.1007/978-1-4939-6960-9_1.

100. Riss, T.; Moravec, R.; Niles, A. Assay development for cell viability and apoptosis for high-throughput screening. In: Chen, T. A Practical guide to assay development and high-throughput screening in drug discovery. CRC Press. 2010, 109-110.

101. Riss, T.; Moravec, R.A.; Niles, A.L.; Duellman, S.; Benink, H.A.; Worzella, T.J.; Minor, L.; Markossian, S.; Grossman, A.; Brimacombe, et al. Cell Viability Assays. In: SITTAMPALAM G. The assay Guidance Manual. Eli Lilly Co., National Center for Advancing Translational Sciences, Bethesda, USA. 2016, p. 10-12. PMID: 23805433.

102. Rangel, K.; Cabral, F.O.; Lechuga, G.C.; Carvalho, J.P.R.S.C.; Villas-Bôas, M.H.S.; Midlej, V.; De-Simone, S.G. Detrimental effect of ozone on pathogenic bacteria. Microorganisms. 2022, 10, 40.doi:10.3390/microorganisms10010040.

103. Heß, S.; Gallert, C. Sensitivity of antibiotic resistant and antibiotic susceptible Escherichia coli, Enterococcus and Staphylococcus, strains against ozone. J Water Health. 2015, 13, 1020-1028. doi: 10.2166/wh.2015.291.

104. Schulz zur Wiesch, .; Engelstadter, J.; Bonhoeffer, S. Compensation of fitness costs and reversibility of antibiotic resistance mutations. Antimicrob. Agents Chemother. 2010, 54, 2085-2095. doi: 10.1128/AAC.01460-09.

105. Von Gunten, U. Ozonation of drinking water: Part II. Disinfection and by-product formation in presence of bromide, iodide or chlorine. Water Res. 2003, 37, 1469-1487. doi: 10.1016/S0043-1354(02)00458-X.

106. Von Sonntag, C.; Von Gunten, U. Chemistry of ozone in water and wastewater treatment from basic principles to applications. IWA Publishing, London, 2012; 306p. doi: 10.2166/9781780400839.

107. Casolari, A. Microbial Death. In physiological models in microbiology; Bazin, M. J., Prosser, J. I., Eds.; CRC Press: Boca Raton, FL, 1988; Vol. II, pp 1-44.

108. Broadwater, W.T.; Hoehn, R.C.; King, P.H. Sensitivity of three selected bacterial species to ozone. Appl Microbiol. 1973; 26:391393. doi: 10.1128/am.26.3.391-393.1973. 
109. Patil, S.; Valdramidis, V.P.; Karatzas, K.A.; Cullen, P.J.; Bourke, P. Assessing the microbial oxidative stress mechanism of ozone treatment through the responses of Escherichia coli mutants. J. Appl. Microbiol. 2011, 111, 136-144. doi: 10.1111/j.1365-2672. 2011.05021.x.

110. Xu P.; Janex, M.L.; Savoye, P.; Cockx, A.; Lazarova, V. Wastewater disinfection by ozone: main parameters for process design. Water Res. 2002, 36, 1043-1055. doi: 10.1016/s0043-1354(01)00298-6.

111. Patil, S.; Bourke, P.; Frias, JM.; Tiwari, B.K. Inactivation of Escherichia coli in orange juice using ozone. Inn. Food Sci. Emerg. Technol. 2009, 10, 551-557. doi:10.1016/J.IFSET.2009.05.011.

112. Pak, G.; Salcedo, D.E.; Lee, H.; Oh, J.; Maeng, S.K.; Song, K.G.; Hong, S.W.; Kim, H.C.; Chandran, K,; Kim, S. Comparison of antibiotic resistance removal efficiencies using ozone disinfection under different $\mathrm{pH}$ and suspended solids and humic substance concentrations. Environ. Sci. Technol. 2016, 50, 7590-7600. doi: 10.1021/acs.est.6b01340.

113. Adler MG, Hill GR. The kinetics and mechanism of hydroxide iron-catalyzed ozone decomposition in aqueous solutions. J. Am. Chem. Soc. 1950, 72, 1884-1886. doi: 10. 1021/ja01161a007.

114. Hoigne, J.; Bader, H. Ozonation of water: role of hydroxyl radicals as oxidizing intermediates. Science. 1975; 190: 782-784. doi: 10. 1126/science.190.4216.782

115. Kang, S.W. Superoxide dismutase 2 gene and cancer risk: evidence from an updated meta-analysis. Int. J. Clinic Exp Med. 2015, 8, 14647-1465. PMID: 26628947

116. Imlay, J.A. Cellular defenses against superoxide and hydrogen peroxide. Annu. Rev. Biochem. 2008, 77, 755-776. doi: 10.1146/ann urev.biochem.77.061606.161055.

117. Pomposiello, P.J.; Demple, B. Redox-operated genetic switches: the SoxR and OxyR transcription factors. Trends Biotechnol. 2021, 19,109-114. doi: 10.1016/s0167-7799(00)01542-0.

118. Greenberg, J.T.; Monach, P.; Chou, J.H.; Josephy, P.D.; Demple, B. Positive control of a global antioxidant defense regulon activated by superoxide generating agents in Escherichia coli. Proc. Natl. Acad. Sci. U.S.A. 1990, 87, 6181-6185. doi: 10.1073/pnas.8 7.16.6181.

119. Delaney, J.M. Requirement of the Escherichia coli dnaK gene for thermotolerance and protection against H2O2. J. Gen. Microbiol. 1990, 136, 2113-2118. doi: 10.1099/00221287-136-10-2113.

120. Rockabrand, D.; Arthur, T.; Korinek, G.; Livers, K.; Blum, P. An essential role for the Escherichia coli DnaK protein in starvationinduced thermotolerance, H2O2 resistance, and reductive division. J. Bacteriol. 1995; 177:3695-3703. doi: 10.1128/jb.177.13.36953703.1995.

121. Loewen, P.; Hu, B.; Strutinsky, J.; Sparling, R. Regulation in the rpoS regulon of Escherichia coli. Can. J. Microbiol. 1998, 44, 707717. doi: 10.1139/cjm-44-8-707.

122. Chaffin, D.O.; Taylor, D.; Skerrett, S.J.; Rubens, C.E. Changes in the Staphylococcus aureus transcriptome during early adaptation to the lung. PLoS One, 2012, 7, e41329. doi: 10.1371/ journal.pone.0041329.

123. Hamelin, C.; Chung, Y.S. Optimal conditions for mutagenesis by ozone in Escherichia coli K12. Mutat. Res. 1974, 24, 271-279. doi: 10.1016/0027-5107(74)90175-4.

124. Hamelin, C.; Sarhan, F.; Chung, Y.S. Ozone induced DNA degradation in different DNA polymerase I mutants of Escherichia coli K12. Biochem Biophys Res Commun. 1977, 77, 220-224. doi: 10.1016/s0006-291x(77)80185-x.

125. Hamelin, C.; Sarhan, F.; Chung, Y.S. Induction of deoxyribonucleic acid degradation in Escherichia coli by ozone. Experientia 1978, 34,1578-1579. doi: 10.1007/BF02034684.

126. Dodd, M.C. Potential impacts of disinfection processes on elimination and deactivation of antibiotic resistance genes during water and wastewater treatment. J. Environ. Moni. 2012, 14, 1754, 1771. doi: 10.1039/c2em00006g.

127. Scott, D.B.M.; Lesher, E.C. Effect of ozone on survival and permeability of Escherichia coli. J. Bacteriol. 1963, 85, 567-576. doi: 10.1128/jb.85.3.567-576.1963. 
128. Hunt, N.K.; Mariñas, B.J. Inactivation of Escherichia coli with ozone: chemical and inactivation kinetics. Water Res. 1999, 33, 263-264. doi: 10.1016/S0043-1354(99)00115-3.

129. Ersoy, Z.G.; Barisci, S.; Turkay, O. Mechanisms of the Escherichia coli and Enterococcus faecalis inactivation by ozone. LWT Food Sci Tecchnol. 2019, 100, 306-313. doi: 10.1016/j.lwt. 2018.10.095.

130. Han, L.; Patil, S.; Boehm, D.; Milosavljević, V.; Cullen, P.J, Bourke P. Mechanisms of inactivation by high-voltage atmospheric cold plasma differ for Escherichia coli and Staphylococcus aureus. Appl. Environ. Microbiol. 2016, 82, 450-458. doi: 10.1128/AEM.0266015.

131. Yu, W.; Zhang, D.; Graham, N.J.D. Membrane fouling by extracellular polymeric substances after ozone pre-treatment: Variation of nano-particle size. Water Research. 2017, 120, 146-155. doi: 10.10 16/j.watres.2017.04.080.

132. Halder, S.; Yadav, K.K.; Sarkar, R.; Mukherjee, S.; Saha, P.; Haldar, S.; Karmakar, S.; Sen, T. Alteration of Zeta potential and membrane permeability in bacteria: a study with cationic agents. Springerplus 2015, 4, 672-686. doi: 10.1186/s40064-015-1476-7.

133. Nagayoshi, M.; Kitamura, C.; Fukuizumi, T.; Nishihara, T.; Terashita, M. Antimicrobial effect of ozonated water on bacteria invading dentinal tubules. J. Endod. 2004, 30, 778-781. doi: 10.1097/00004 770-200411000-00007.

134. Russell, A.D. Similarities and differences in the responses of microorganisms to biocides. J. Antimicrob. Chemother. 2003, 52, 750763. doi: $10.1093 / \mathrm{jac} / \mathrm{dkg} 422$. 